\title{
Windows of Opportunity: Early Childhood Development Prospects in South Africa
}

\author{
Corinne Meier \\ Department of Early Childhood Education, University of South Africa, PO Box 392, \\ Pretoria, 0003, Republic of South Africa
}

\begin{abstract}
KEYWORDS Brain Development. Policy Development. Government Responsibility. Care. Human Rights. Diversity. Child Development Theories

ABSTRACT Early childhood development (ECD) is regarded as critical for establishing the foundation for academic success in schools. The results of the South African Annual National Assessment systemic evaluation (ANA) register particularly poor school performance in the first three years of school in literacy and numeracy. The question that comes up irresistibly, therefore, is whether the provision of ECD in South Africa is opening windows of opportunity for young children, and if so, whether such windows are being opened to best advantage. These questions will be examined through a systematic literature review by utilizing a fusion of contextual as well as conceptual review methods which will focus on selected child development theories that are predicated on the huge potential that every child has for self-actualisation, the latest findings on neurological research, the universal right to education and policy development in the ECD field. These issues are mirrored against 'care' as the overarching conceptual framework. It is found that the South African government seems to display a mediocre 'caring-about' attitude towards the provision of ECD in that it contributes funds and policies but do not see to the implementation thereof. Several interventions are considered imperative prerequisites for immediate implementation in order to vitalise the prospects of ECD in South Africa.
\end{abstract}

\section{INTRODUCTION}

Social media and civil society voice the drastic claim that education in South Africa is largely dysfunctional and is failing a large part of society (Cape Times 2014: 9; Atmore 2013: 152). Jonathan Jansen (Jansen 2008: 9), educationist and Rector of the University of the Free State says: "The effects on the youth of the failing in the school system are devastating as both national examinations and provincial tests show not only a stagnation in learning performance among young people but in some cases, actually a regression in learning achievements in the poor provinces". In his opinion: "One of the most serious errors committed by overzealous politicians in South Africa is to use education policy as a blunt instrument to try and solve complex problems that require fine-tuned strategies for change. This is why the education sector has produced more policies than any other

Address for correspondence

Prof. Corinne Meier

Department of Early Childhood Education

University of South Africa

PO Box 392

Pretoria, 0003

Republic of South Africa

Telephone: +27 123617232

E-mail: meierc@unisa.ac.za with the least to show for all this activism in terms of learning outcomes" (Jansen 2012b: 17).

Many education and civil society activists such as Emeritus Archbishop Desmond Tutu, Prof Jonathan Jansen and Dr Mamphela Ramphele, former UCT vice-chancellor served as government's conscience over a period of time and have cautioned government that education is being compromised through bad decision making. They have offered their sage advice year after year but government is slow to respond (Kadalie 2013: 12). Recently Atmore (2014: 9) remarked that only seven main political parties that contested the 2014 national elections (20 parties registered for the elections) in South Africa had proclaimed policies on Early Childhood Development (ECD). Atmore had the following to say on the content of these policies: "Clearly none of the seven parties knows anything about early childhood education. They seem to have hurriedly conjured up thoughts on early childhood development. All the responses are short in detail and make promises they cannot hope to keep".

Public trust in the education system and government integrity in dealing fairly with education remains at a low ebb (Faber 2014a: 5; Jansen 2012a: 39). Instead of heeding the warnings as cited here, government lethargy and inaction persists (Chang 2011: 31). Dr Ramphele has as- 
serted emphatically that the education system today is worse than it ever was, even under apartheid (Jones 2012). Furthermore, remedial strategies involving classroom-based interventions appear to have little impact (O'Carroll and Hickmann 2012), and the Department of Education notes that grade repetitions were the highest in Grade 1 due to serious deficiencies in school entrants' learning abilities and unsuitable learning programmes beyond the reach of entrants' capacity (Department of Education 2007).

A compelling body of evidence shows that if we are to give our children a better chance of successful schooling, the right foundations for learning must be laid in the period before formal schooling starts. In fact it has become widely current in recent times that the first 1000 days from conception to the second birthday are the most decisive for an individual's entire life (Ebrahim 2014; Faber 2014b: 8; Grantham-McGregor et al. 2007; Snow et al. 1998). This period before formal schooling is typified in South Africa as the Early Childhood Development (ECD) sector encompassing pre-Grade R for children from birth to four years, and Grade $\mathrm{R}$ for children aged five to six years (Richter 2012: 3).

What is however disturbing, is that according to the 2011 General Household Survey released by Statistics South Africa (Statistics South Africa 2011), only 34\% of children in the group ranging from infancy to four years old, had the benefit of education in early childhood institutions while the rest were dependent on whatever school preparation was forthcoming from their home environment.

\section{Aim of the Study}

The fact that only 34\% of young children in South Africa are receiving ECD preparation for a school career must be considered an impediment that South Africa can ill afford, given conditions prevailing in education today. The aim of this paper is to attend to the question whether the provision of ECD in South Africa is opening windows of opportunity for young children, and if so, whether such windows are being opened to best advantage.

\section{METHODOLOGY}

The aim of the paper will be explored through a systematic literature review by utilising a fu- sion of contextual as well as conceptual review methods. A thoughtful and informed review of relevant literature puts the researcher in a framework of apposite studies where information from an exciting body of completed and recorded work can be considered in light of the researcher's own concerns and situation (Fraenkel and Wallen 2010: 67), namely as teacher trainer in ECD is juxtaposed in this paper with the severely excoriated ECD environment in South Africa (Cape Times 2014: 9; Faber 2014a: 5; Atmore 2013: 152; Richter 2012: 3; Jansen 2008: 9).

The contextual review will include a description of the ECD landscape in South Africa, the right to education, and the policy frameworks for ECD in South Africa. The conceptual review will include a critique of the 'ethics of care' concept where the concept will be taken apart, the parts will be examined and then put together again for better understanding (Walker and Avant 2014). Then a discussion will be made on how the contextual review imprinted on the conceptual review when the concept 'ethics of care' is related to the South African government's provision of ECD.

The systematic contextual and conceptual literature review was done by investigating general references (Current Index to Journals in Education (CIJE), Resources in Education (RIE), ERIC online and Social Sciences Citation Index (SSCI)) and abstracts to obtain a wide view of the most recent literature and commentaries on the topic of ECD in South Africa. Then a more focused review was done by using primary sources where researchers communicated their research findings on ECD related topics in South Africa directly in journal articles. Furthermore, in this paper the contextual review relied heavily on government published statutes, policies and reports in the field of education and ECD in particular. Secondary sources, affirming description of and commentary on the work of others (Fraenkel and Wallen 2010: 68; De Vos et al. 2005: 315) were used to get a feel of how ECD is generally received in South Africa.

The internet, using the World Wide Web and reverting to search engines such as Google, Google Scholar and Yahoo was also used. The advantages of using an internet search includes currency, access to a wide variety of material and immediacy (open 24 hours a day), but the disadvantages of disorganization, time consuming, uncertain reliability and lack of credibility 
(Fraenkel and Wallen 2010: 68) limited the use of the internet in searching for literature on ECD in South Africa.

\section{Contextual-Conceptual Literature Review}

\section{What is Early Childhood Development?}

Early childhood development is defined as a comprehensive approach to policies, practices and programmes for children from birth to nine years. These policies, practices and programmes are very specifically focussed on the particular developmental stages of the young child. Besides the age demarcation from birth to the nine years much can be said about the child's social, psychological, emotional and cognitive development during this period.

Application of prominent child development theories gives guidelines to understand and assist the child to develop in a balanced way. It is critical that adults, caregivers and policymakers understand where children in their care are coming from and what their dispositions are. Specifically, a number of models and theories on child development for example Maslow's needs hierarchy (1954), Erikson's psychosocial theory (1950), Bronfenbrenner's ecological model (1979), and Vygotsky's socio-cultural theory (1978) have stood the test of time in providing frameworks for understanding children's development and learning. This list of theories and models is by no means exhaustive but they do offer a critical point of departure towards understanding the young child and why ECD is indispensable.

The above theories of child development underline the huge potential that every young child has for self-actualisation which should be the focus for every caregiver's pedagogic enterprise. Theories have long been used to inform and guide practice. There are however also recent research findings that put a different lens on the young child's development. The focus of the next section will be on the impact of brain development pertaining to the young child.

Brain development is the growth of the main cellular components of the brain, called neurons. At birth, neurons are primed to organise themselves in response to the human individual's new environment, no matter the culture, climate, language, or lifestyle. The newly generated neurons migrate to different parts of the developing brain to self-organize into different brain struc- tures. Once the neurons have reached their regional positions, they extend axons and dendrites, which allow them to communicate with other neurons via synapses. Synaptic communication between neurons leads to the establishment of functional neural circuits that mediate sensory and motor processing, and underlie behaviour (Neural Development 2013).

Throughout life, the neural network reorganises and reinforces itself in response to new stimuli and learning experiences. The development of synapses occurs at an astounding rate in response to young children's experiences during the early formative years (Zero to three, 2009). By the time a child is five years old the fundamental brain network is complete, thus most brain development occurs in the first five years of a child's life.

Some synaptic pathways are worn deeper and remain intact, failing which synaptic pruning will set in and many synapses will gradually be discarded. This is to say the principle of 'use it or lose it' applies - the organism perceives underutilisation as redundancy, discarding what it does not need to conserve resources. Regardless of the general environment, all children need stimulation and nurturing for healthy development, failing which their brain development may be impaired and because the brain adapts to its environment as a constant principle, it will adapt indiscriminately to a negative as much as to a positive environment (Shonkoff and Phillips 2000).

Researchers believe that there are periods during which the human organism is particularly susceptible to the development of certain capabilities (Neural development 2013; Zero to three 2009; Perry 2001). These periods are referred to as 'windows of opportunity' in the developmental process. The period from birth to seven years is regarded as a special 'window of opportunity' during which the brain is most capable of forming permanent conditioning impressions from experiences to which it is exposed. As noted, if certain synapses and neural pathways are not repeatedly activated by stimulating experiences in this period, they may be discarded, and the capabilities they promised may be lost (Perry 2001). This fact strongly underlines the need for early stimulation.

Prof James Heckman, a Nobel laureate and economist, has set out an economic case that shows that the rate of economic return on peda- 
gogic intervention as an investment made in the early formative years of a child's life is significantly higher than for any other stage. He argues that, on productivity grounds, it makes sense to invest in young children from disadvantaged environments. Substantial evidence shows that these children are more likely to commit crime, have out-of-wedlock births and drop out of school. Early interventions that remediate the effects of adverse environments can reverse some of the harm of disadvantage and have a high economic return. Enriched interventions targeted towards children in disadvantaged environments are cost-effective remedies for reducing crime and the factors that breed crime, and this for raising productivity in schools and in the workplace. The later in life we attempt to repair early deficits, the costlier the remediation becomes (Heckman and Masterov 2007).

Seen against the background of child development theories as well as research findings regarding the influence of early stimulation, it would be cruel to deprive children of stimulation that could help them to develop their full potential; in fact, such deprivation would amount to a human rights violation. At the heart of this paper is an approach which recognises the right of children, including the very young, to quality education that will empower them to meet their own needs across board.

\section{Right to Education}

According to the International Covenant on Economic, Social and Cultural Rights (1976), the right to education includes the right to free, compulsory primary education for all, throughout all stages of childhood and beyond. Although the Convention on the Rights of the Child does not impose explicit obligations to provide early childhood education, the Committee on the Rights of the Child interprets the right to education as beginning at birth and as closely linked to the child's right to maximum development. It calls on governments to ensure that young children have access to education designed to promote their well-being, and stresses the right to optimum development.

The Right to Education Project (RTE), established by the United Nations in 2000 proposes governments, as prime duty-bearers, to have respect, protect and fulfil the right to education by making education available, accessible, ac- ceptable and adaptable to all children (Right to Education 2012: 19-20).

\section{Policy Frameworks for ECD in South Africa}

The South African government's commitments to children flow from South Africa's ratification of international child rights conventions, such as the United Nations Convention on the Rights of the Child (1990) and the African Charter on the Rights and Welfare of the Child (1999). Children's rights to ECD provision are also implied through a number of other constitutional rights such as the South African Constitution, the Children's Act, white papers and ECD policies.

The Constitution of South Africa (Republic of South Africa 1996) provides the legal foundation for the existence of the Republic, sets out the rights and duties of its citizens, and defines the structure of the government. Chapter two is a bill of rights which enumerates the civil, political, economic, social and cultural human rights of the people of South Africa. In Section 29 the universal right to basic education is stipulated.

The Children's Act, No. 38 of 2005 (Republic of South Africa 2005b) and the Children's Amendment Act, No. 41 of 2007 (Republic of South Africa 2007) provides for an ECD focus predominantly on the care and protection of children from birth to four years old. By 'care' the Act means providing the child with guidance and direction as well as securing the child's education and upbringing. The Act must be implemented by organs of the state and the Act places an obligation on the State to respect, protect, promote and fulfil the child's right to education, care and protection. The Minister for Social Development is tasked with developing a comprehensive national strategy aimed at securing a properly resourced, coordinated and managed ECD system that promotes and monitors the sound physical, psychological, intellectual, emotional and social development of children.

The following White Papers have referred to ECD: The Interim Policy for Early Childhood Development (1996) (Department of Education 1996) established the broad framework for ECD outlined by the 1995 White Paper on Education and Training (Department of Education 1995). Provision for ECD services was made in the 1997 White Paper on Social Welfare (Department of 
Welfare 1997); and in 2001 the Department of Education's Education White Paper Five on Early Childhood Development (Department of Education 2001) identified a number of critical areas to be addressed in an integrated ECD strategy. White Paper Five envisaged universal access to Grade $\mathrm{R}$ for five-year old children by 2010. It also called for an inter sectoral strategic plan that would target appropriate and integrated ECD services and programmes for children younger than five years; an improvement in the quality of pre Grade R programmes, and inclusion of health, nutrition, appropriate curricula and practitioner development.

The National Integrated Plan (NIP) for ECD (2005-2010) (Republic of South Africa 2005a) provided a framework for how the concept of 'integration' might be operationalised in the ECD sector. The NIP for ECD was therefore developed by government because "focusing on a single aspect of ECD does not yield sustainable results. The integrated approach includes programmes in health, nutrition, water and sanitation, early learning and psychosocial care”. Institutional arrangements include political leadership through the Ministers of Health, Education and Social Development and the Minister in the Office of the President to provide access for all young children to a range of services and programmes to support their development, to create environments for children where they can grow and thrive and to create opportunities for children to be better prepared for formal school (Biersteker 2008).

The National early learning and developments standards for children from birth to four years (NELDS) was released in 2009 (Department of Education and UNICEF 2009). The NELDS and its purpose are to present a multidimensional transformatory vision for stakeholders in early childhood education. It is expected that the NELDS will improve children's learning and development through a focus on child-centred practices and holistic development. For policy makers it is expected to be a tool to develop indicators for school readiness, and to monitor and evaluate progress of children on a national scale (Ebrahim 2014: 70).

In light of the above policy frameworks, the impression may be gained that adequate provision is being made for young children in line with international standards and expectations, but this picture needs to be adjusted substantially on closer scrutiny.

\section{Early Childhood Development in South Africa}

The White Paper on Early Childhood Development of 2001 pointed out that children raised in poor families are most at risk of infant death, low birth-weight, stunted growth, poor adjustment to school, increased repetition and school dropout. The challenge in 2011 was seen as increasing access to ECD programmes, particularly for poor children, and to improve the quality of these programmes. ECD has come to be regarded as critical for establishing the foundation for academic success in schools for children from disadvantaged backgrounds. This lead government to expand ECD through funding both Grade $\mathrm{R}$, mainly in public schools for children aged 5 or 6 , and through subsidizing provision of community-based care centres for children aged birth to four years. The former is funded by the Department of Basic Education, the latter by the Department of Social Development.

Reports published on the implementation of ECD policy in South Africa since the White Paper 2001 however portrays a bleak picture. In 2009/2010 a survey commissioned by the Department of Social Development, Department of Basic Education and UNICEF (2011), entitled 'Tracking Public Expenditure and Assessing Service Quality in Early Childhood Development in South Africa' was done in three provinces in 300 public schools offering Grade R, 300 community-based ECD facilities registered with the Department of Social Development, and 90 nonregistered community-based ECD facilities. A programme quality index was used for programme assessments, observing activities and assessing learner portfolios. Based on not very strict criteria, good quality programmes were only found in $45 \%$ of public schools, in $29 \%$ of registered ECD institutions and in 11\% of unregistered community facilities. Programmes depend to a large degree upon learning and teaching support material (LTSM), but some public schools did not even have tables and chairs for children; 32\% of public schools lacked a reading corner, outside equipment, wheel toys, jungle gyms, swings, as well as books. Paper was unavailable in 35\% of classes. An infrastructure index based on the combination of all infrastructure items found particularly large infrastructure deficiencies in one of the provinces 
(Department of Social Development, Department of Basic Education and UNICEF 2011: vi).

In 2011 the National Planning Commission (NPC) report stated that "the quality of early childhood education and care for poor black communities was generally poor and underfunded by government. Despite the policy, therefore commitment to implementation in the poorest communities lags behind" (Republic of South Africa 2011a: 4).

In 2012, on the eve of the review of the $\mathrm{Na}$ tional Integrated Plan for Early Child Development (2005-2010), the Department of Performance Monitoring and Evaluation in the Presidency and the Inter-Departmental Steering Committee on Early Childhood Development commissioned a Diagnostic Review of the prevailing ECD paradigm, current services, human resources, funding and impact. The Diagnostic review is based on a review of 112 relevant policy documents, evaluations and studies, as well as consultations with ECD practitioners, civil society, researchers and government officials at national, provincial and local levels. The findings published in the report indicated persistent fragmentation in legislative and policy frameworks, uncoordinated service delivery, limited access to ECD services, variable quality of ECD services and limited inter-sectorial coordination (Richter 2012).

Ebrahim (2014: 69) reports that the introduction of the NELDS in 2009 was seen as a critical curriculum initiative for the country's social and economic transformation and development; however endeavours to live to the full expectations awakened by the document do not seem to materialise. Ebrahim (2014: 70) postulates the following reasons for this failure: fragmentary field, lack of unified vision, absence of a critical mass, lack of capacity, reluctance to move out of the comfort zone of existing practices and resignation of lead people in the early childhood directorate.

The field of ECD in South Africa is currently highly fragmented, comprising of small interest groups without a unified voice or vision. A vast number of documents on the state of ECD in South Africa have been published since 2001. Amongst these are national policies and programmes, white papers, position papers and plans, audits and evaluations, overviews and proposals (Richter 2012) but it is evident that only little impact was made in the provision of
ECD for the young children of South Africa although the general core of each and every document on ECD reflects a commitment to the 'care', protection and well-being of children. In the next section a discussion will follow on 'care' as a conceptual framework against which provision of ECD by the government will be evaluated.

\section{‘Care’ as Conceptual Framework}

'Care' is referred to in the first paragraph of the Children's Act which was passed to give effect to the rights of children as contained in the South African Constitution. Care as referred to in the Children's Act means "providing the child with guidance, direction and securing the child's education and upbringing" (Republic of South Africa 2005b). The issue of 'care' is thus the main focus of the Children's Act and therefore also of the following discussion. This paper is grounded in the 'ethics of care' concept coined by Nel Noddings (1984) in which she argues that caring should be the foundation for ethical decision-making in the lives of children. This paper is furthermore informed by the work of Joan Tronto, a political theorist, who built on the works of Noddings, but took the argument further by saying that in society, only lip service is paid to the issue of ethical decision-making and the dignity and care of ordinary people. Tronto sees herself as an activist in her writings against the continued injustices that make inroads on the care of ordinary people, young and old, in the world (Tronto 1993: ix).

'Care' in the context of this paper, means the support and assistance one individual requires from another where those in need of care are 'inevitably dependent', that is, dependent because they are too young or too ill to manage daily self-maintenance on their own. People need to be cared for or nurtured throughout their lives by other people, sometimes more urgently and more completely than at other times (Kittay et al. 2005: 443). All caregiving involves a direct, intimate relationship between two or more people, occurs in a psychological, social and lived context that has shaped, and do shape the experiences of the participants in the caring relationship. Caring is thus fundamentally a practice that comprises certain moral and ethical virtues (Kittay et al. 2005: 443). 
Norms surrounding both the giving and receiving of care, are conditioned by cultural, economic and political circumstances. The 'giving of care' is therefore firstly a question of justice (who gets how much) and secondly the quality of the interactions between carer, cared for and the larger community (Kittay et al. 2005: 443). Justice is measured by the quality of the interactions between carer, cared for and how well the carer can step out of his own personal frame of reference into the other's frame of reference or context. This means how well the carer can consider the needs of others (Smeyers 1999: 235).

Virginia Held (Held 1999) argues that care should be the wider moral framework into which justice should be fitted. She warns against one clearly unsatisfactory possibility; that of thinking that justice is a value appropriate to the political domain, while care belongs to the private domains of family and friends. Justice without a notion of care is incomplete (Tronto 1995: 167). Care is badly needed in the political domain. Justice deals with moral minimums; care, in contrast with what is above and beyond the basic call of duty. Caring well for children involves much more than honouring their rights to education or adequate food. The care ethic requires that we constantly return to the real world of daily lives to generate our political positions (Tronto 1995).

Care presupposes trust. Trust indicates an attitude of optimism that the goodwill and competence of another will extend to cover the overall domain of interaction between individuals. It also implies the expectation that the one trusted will be directly and favourably moved by the thought that the trusting party reposes trust and confidence in the one trusted (Smeyers 1999: 242). Trust reflects the value of respect for persons. The one trusted completes the trusting relationship by committing themselves to live up to what is expected of them (Appelbaum 1995: 452).

An ethic of care is best expressed as an activity rather than a set of principles. Taking care as a societal value, means that we pay attention to others' needs, that we take up our responsibility to do something about such needs; that we develop the competencies and the adequate means to achieve that, and that we in the end listen how others evaluate our actions. Justice prevails when each is attended to, each is heard, each is recognised, and crucially, no one's wel- fare is ignored or dismissed (Carse and Lindermann 1996: 23).

Besides care, justice and trust, 'integrity' appears as a necessary condition. Integrity seems important to finding a balance between what one experiences externally and internally as 'good' in leading a non-corrupt existence. As a social virtue, integrity is thus tightly connected to viewing oneself as a member of an evaluating community and to caring about what that community endorses (May 1996). In this sense, the caring that provides the framework for persons of integrity might offer the avenue that leads from personal commitment to greater social justice (Smeyers 1999: 249).

Nel Noddings distinguishes between 'caring-for' and 'caring-about'. 'Caring-for' entails face-to-face encounters in which one person cares directly for another. 'Caring-about' is something more general, and takes us more into the political realm. We may be concerned about the suffering of those in poor countries and wish to do something about it such as giving to a charity. As Noddings puts it, 'caring-about' involves 'a certain caring neglect'. She explains 'caring neglect' as follows: 'One is attentive just so far. One assents with just so much enthusiasm. One acknowledges. One affirms. One contributes five dollars and goes on to other things' (Noddings 1984: 112). Noddings urges that 'caring-about' needs more attention. We learn first what it means to be cared-for. 'Then, gradually, we learn both to care for and, by extension, to care about others'. This 'caring-about,' Noddings argues, is almost certainly the foundation for our sense of justice (Sanford 2013). Tronto (1993: 180) is adamant in this regard that "Care is a central concern of human life. It is time that we began to change our political institutions to reflect this truth”.

\section{OBSERVATIONS AND DISCUSSION}

How does the 'ethics of care' relate to the South African government's provision of ECD? The young child in the ECD phase is in the most susceptible of developmental stages. Longstanding, as well as recent theories and research done on child development are most informative as regards windows of opportunity for the young child (Ebrahim 2014; Faber 2014b: 8; Grantham-McGregor et al. 2007; Snow et al. 1998). But this young child is dependent on someone 
who cares enough to open these windows of opportunity so that the child can step out and explore the world on a road to live up to realising their full potential.

Urgent appeals contained in reports on ECD in South Africa have been issued over decades to solicit government intervention to assist ECD nationally (Department of Social Development, Department of Basic Education and UNICEF 2011: vi; Republic of South Africa 2011a: 4; Richter 2012; Ebrahim 2014: 69). Government has responded by signalling commitment to ECD by ratifying international documents affirming children's rights and reiterating its support for the South African Constitution, the Children's Act, the relevant white papers and several ECD policies (Republic of South Africa 2005b; Republic of South Africa 2007; Department of Education and UNICEF 2009).

However government, as the author of the Children's Act and custodian of children in South Africa does not make the grade if the Children's Act which sets out principles for the care and protection of children is considered in context with an 'ethics of care' framework. Care as referred to in the Children's Act means "providing the child with guidance, direction and securing the child's education and upbringing" (Republic of South Africa 2007). With only 34\% of young children participating in structured ECD activities (Statistics South Africa 2011), and government's report that ECD for underprivileged black communities is exceptionally poor in every respect, that it is generally underfunded by government, and that the implementation of ECD in the poorest communities lags behind (Republic of South Africa 2011a) it follows that South African government decision-making on ECD lacks an 'ethic of care' (Noddings 1984). It is largely evident that continued injustices perpetrated towards ordinary people in South Africa and in this case young people militate against the principle of care (Tronto 1995). Here again, if justice is measured by the quality of the interactions between carer, cared for and how well the carer can step out of his own personal frame of reference into the other's and how well the carer can consider the other's point of view and needs, the South African government does not make the grade. Reports of malfeasance in government circles persist; in fact graft and poor performance in key areas of government responsibility, run together like a horse and carriage (At- more 2014: 9; Chang 2011: 2). Consequently politicians will probably not be able to step out of their own personal frame of reference into that of the poor and the young, and see their needs.

Care, furthermore presupposes trust, but if public trust in the education system and government integrity in caring about education outcomes remains at low ebb, there can be no question of real care, which reduces all talk about care. An ethic of care is best expressed as an activity rather than a set of principles but if the education policies produced by government remain in the realm of lip service (Ebrahim 2014: 70; Richter 2012) more so in education than any other area, it follows that government's pictative endeavours to display care for ordinary people or the young can be defined as half-hearted at best.

Integrity is integral to caring. As a social virtue, integrity is thus tightly connected to viewing oneself as a member of an evaluating community and to caring about what that community endorses (May 1996). But if government does not react to voices from civil society that sound warnings over a long period that education is being compromised through bad decision making (Kadalie 2013: 12; Atmore 2014b: 9) then caring is vitiated by a lack of integrity.

Government furthermore seems to display a mediocre 'caring-about,' attitude towards the provision of ECD in that it contributes funds and policies (like tossing a coin in a beggar's hat) and 'then goes on to other things' (Noddings 1984: 112). Joan Tronto (1993: 180) firmly states in this regard: "Care is a central concern of human life. It is time that we began to change our political institutions to reflect this truth".

\section{CONCLUSION}

The prospects of ECD in South Africa are two sides of the same coin. The one side looks vigorous when one looks at all the policy frameworks and commissions in place that monitor ECD. The other side of the coin reflects the discouraging findings of reports on the implementation and quality of ECD which mirrors gaps between policy and practice, intersectorial differences without a shared vision, goals and accountability, and significant gaps in service delivery to poor communities. Thus it can be concluded that the provision of ECD in South Afri- 
ca is not opening windows of opportunity for young children, therefore there are very view opportunities to be utilised to best advantage by children in South Africa. In this regard it can be supposed that school readiness is not being advanced and more essentially the enormous innate potential of young children may remain tragically, a closed book to the detriment of the population at large and the future social and economic welfare of the country.

In conclusion, if the 'ethics of care' is infused into all our efforts towards providing quality ECD, and if interventions during the earliest formative years of children's lives is given the highest priority, then, and only then, the windows of opportunity for South Africa's young children will be opened wide and they will be able to use and capitalise fully on their innate potentialities and bring us closer to a healthier, safer and stronger South Africa.

\section{RECOMMENDATIONS}

A broad range of interventions in ECD are desperately needed. The following recommendations are considered a top priority for immediate implementation in order to vitalise the prospects of ECD in South Africa.

Firstly, an 'ethics of care' commitment should be adopted and infused into all government efforts to provide quality ECD for all communities in South Africa. An 'ethics of care' should inculcate trust, integrity, social justice and both a 'caring-for' and a 'caring-about' attitude from government to ensure a life-cycle of complete caring.

Secondly, individuals with the best possible expertise and specifically appropriate aptitudes should be recruited and installed in influential leadership and mentoring positions in the ECD sector to assist government with policy implementation.

Thirdly, government should urgently improve funding, infrastructure, the supply of learner support materials and equipment for ECD especially for children in poor circumstances, rural areas, and informal urban areas as well as for children with disabilities. This means that equity of access, as well as equity of achievement should be obtainable for all marginalised communities.

Fourthly, effective parent support programmes should be introduced and promoted that acknowledges and reinforces the importance of early stimulation and positive parenting for young children. Parent support programmes should be considered the backbone of governments' efforts to ensure early stimulation of young children.

Fifthly, a renewed focus on training in ECD principles and practices is crucial in an effort for ECD practitioners to know 'how' to open the windows of opportunities for young children.

\section{REFERENCES}

Appelbaum B 1995. Creating a trusting atmosphere in the classroom. Educational Theory, 45: 443-452.

Atmore E 2014. Early Childhood Education Is Not Just Kissing Babies At Election Time. Cape Times, July 1, P. 9.

Atmore E 2013. Early Childhood Development in South Africa - progress since the end of apartheid. International Journal of Early Years Education, 21(23): $152-162$.

Biersteker L. 2008 Meeting the Comprehensive Social Security Needs of Young Children $(0-9)$ in South Africa - What is Needed to Achieve Access to a Comprehensive and Integrated Social Protection System? Paper commissioned by the Alliance for Children Entitlement to Social Security 2008. From <http: //acess.org.za/home/images/stories/BierstekerIntegrated-ECD-Service-Delivery-Final.pdf $>$ (Retrieved on 14 July 2014).

Bronfonbrenner U 1979. The Ecology of Human Development: Experiments by Nature and Desing. Cambridge, MA: Harvard University Press.

Cape Times 2014. "20 Years On: What Has Changed For Children?” March 14, P. 9.

Carse LC, Lindemann NL 1996. Rehabilitation care. Kennedy Institute of Ethics Journal, 6: 19-35.

Chang D 2011. Truth is a Bitter Pill, Even for a Miracle Nation. City Press, May 7, P. 31.

De Vos AS, Strydom H, Fouche CB, Delport CSL 2005. Research at Grassroots. $3^{\text {rd }}$ Edition. Pretoria: Van Schaik.

Department of Basic Education, Department of Social Development, and UNICEF. 2011 Tracking Public Expenditure and Assessing Service Quality in Early Childhood Development in South Africa. From <http: //www.unicef.org/southafrica/resources_ 8119.html $>$ (Retrieved on 3 July 2013).

Department of Education. White Paper on Education and Training 1995. From <http: //www. education.gov.za/LinkClick.aspx?fileticket $=855 \mathrm{fT}$ 9w3A2U\%3Dandtabid=191andmid=484> (Retrieved on 3 July 2013).

Department of Education. Interim Policy for Early Childhood Development 1996. From <http: // www.education.gov.za/LinkClick. aspx? fileticket= BY857uQmmO0\%3 Dandtabid=390 andmid=1125> (Retrieved on 3 July 2013).

Department of Education. Education White Paper 5: Meeting the Challenge of Early Childhood Development in South Africa 2001. From <http: // www.info.gov.za/view/Download FileAction?id= 127937> (Retrieved on 3 July 2013).

Department of Education. 2007. Progress Report to the Minister of Education - Ministerial Committee on Learner Retention in the South African Schooling 
System. From <http: //www.info.gov.za/view/ DownloadFileAction?id=79404> $($ Retrieved on 9 July 2013).

Department of Education and UNICEF 2009. National Early Learning and Developments Standards for Children from Birth to Four Years (NELDS). Pretoria: UNICEF.

Department of Welfare. White Paper for Social Welfare 1997. From <http: //www.info.gov.za/view/ DownloadFileAction?id $=127937>($ Retrieved on 3 July 2013).

Ebrahim HB . Foregrounding silences in the South African National Early Learning Standards for birth to four years. European Early Childhood Education Research Journal, 22(1): 67-76.

Erikson EH 1950. Childhood and Society. New York: Norton.

Faber T 2014a. Achilles Heel of Education Exposed. The Mercury, March 19, P. 5.

Faber T 2014b. Solving SA's Problems Begins in Cradle and Crèche. Cape Times, March 27, P. 8.

Fraenkel JR, Wallen NE 2010. How to Design and Evaluate Research in Education. $7^{\text {th }}$ Edition. Boston: McGraw-Hill.

Grantham-McGregor S, Bun Cheung Y, Cueto S, Glewwe P, Richter L, Strupp B, the International Child Steering Group. 2007. Child development in developing countries I: Developmental potential in the first five years for children in developing countries. Lancet, 369: 60-70.

Heckman JJ, Masterov DV 2007. The Productivity Argument for Investing in Young Children. Paper delivered at the TW Schultz Award Lecture at the Allied Social Sciences Association Annual Meeting. Chicago.

Held V 1999. The meshing of care and justice. Hypatia, 10: 128-132.International Covenant on Economic, Social and Cultural Rights. United Nations Human Rights 1976. From <http: //www.ohchr.org/ EN/ProfessionalInterest/Pages/CESCR.aspx> (Retrieved on 2 July 22013)

Jansen J 2008. Future Looks Bleak for Education System. Sunday Independent, November 2, P. 1-2.

Jansen J 2012a. Mediocrity does not rule, okay? Mail and Guardian, May 24, P. 1-2.

Jansen J 2012b. Here's the blunt truth. The Times, October 25, P. 17.

Jones M 2012. 'It will make 1976 look like a picnic'. Cape Times, April 18, P. 6.

Kadalie R 2013. Freeze on Education. Citizen, January 25, P. 12.

Kittay EF, Jennings B, Wassunna AA 2005. Dependency, difference and the global ethic of long term care. The Journal of Political Philosophy, 13(4): 443-469.

Maslow A 1954. Motivation and Personality. New York: Harper Publishers.

May L 1996. Integrity, self and value plurality. Journal of Social Philosophy, 27(1): 123-129. Neural Development 2013. From <https: //en.wikipedia. org/wiki/Neural_development> (Retrieved on 1 July 2013).

Noddings N 1984. Caring. A feminine approach to ethics and moral education. Berkeley: University of California Press.

O’Carrol S, Hickman R 2012. Narrowing the literacy gap: Strengthening language and literacy development between birth and six years for children in South Africa. Cape Town: Wordworks.
Perry BD 2001.The Neuroarcheology of Childhood Maltreatment: The Neurodevelopmental Costs of Adverse Childhood Events. Child Trauma Academy. From <www.childtrauma.org/ctamaterials/ Neuroarcheology.asp> (Retrieved on 5 July 2013).

Republic of South Africa 1996. Constitution of the Republic of South Africa. Pretoria: Government Printers.

Republic of South Africa 2005a. National Integrated Plan for Early Childhood Development in South Africa 2005-2010. From <http: //www.unicef.org/ southafrica/SAF_resources_nip.pdf $>$ (Retrieved on 5 July 2013).

Republic of South Africa 2005b. Children's Act 38 of 2005. From <http: //www.justice.gov.za/legislation/ acts/2005-038\%20childrensact.pdf > (Retrieved on 5 July 2013).

Republic of South Africa 2007. Children's Act 41 of 2007. From <http: //www.justice.gov.za/legislation/ acts/2005-038\%20childrensact.pdf > (Retrieved on 6 June 2013).

Republic of South Africa 2011a. Ntional Planning Commission - Diagnostic Overview. From <http: / www.info.gov.za/view/Download FileAction?id= 147192> (Retrieved on 3 July 2013).

Richter L 2012. Diagnostic Review of Early Child Development 2012. From<http: //www.info.gov.za/ view/DownloadFileAction?id=170644 $>$ (Retrieved on 7 July 2013).

Right to Education Annual Report 2012. From <http: / /www.right-to-education.org/sites/r2e.gn.apc.org/ files/RTE\%20Annual\%20Report\%202012_0.pdf> (Retrieved on 1 July 2013).

Sanford MK, Noddings N 2013. The Ethics of Care and Education. From <http: //mksanford. wikispaces. com/ file/view/Nel+Noddings. doc $>$ (Retrieved on 25 July 2013).

Shonkoff JP, Phillips DA 2000. From Neurons to Neighborhoods: The Science of Early Childhood Development. Washington, D.C.: National Academy Press.

Smeyers J 1999. 'Care' and wider ethical issues. Journal of Philosophy of Education, 33(2): 233-251.

Snow CE, Burns MS, Griffin P (Eds.) 1998. Preventing Reading Difficulties in Young Children. Washington, DC: National Academy Press.

Statistics South Africa General House Hold Survey. 2011. From <http: //www.statssa.gov.za/publications/ P0318/P0318April2012.pdf > (Retrieved on 25 June 2013).

Tronto J 1993. Moral Boundaries: A Political Argument for an Ethics of Care. New York: Routledge.

Tronto J 1995. Care as a basis for radical political judgements. Hypatia, 10: 141-149.

Universal Declaration of Human Rights 1948. From <http: //www.un.org/en/documents/udhr/> (Retrieved on 2 July 2013).

Vygotsky LS 1978. Mind in Society:The Development of Higher Psychological Processes. Cambridge, MA: Harvard University Press.

Walker LO, Avant KC 2014. Strategies for Theory Construction in Nursing. Essex: Pearson Education Limited.

Zero to Three Brain Development: Frequently Asked Questions 2009. From <www.zerotothree.org/site/ PageServer?pagename=ter_key_brainFAQ $>($ Retrieved on 5 July 2013). 